Article

\title{
Rice-Residue Management Practices of Smallholder Farms in Vietnam and Their Effects on Nutrient Fluxes in the Soil-Plant System
}

\author{
Dao Trong Hung ${ }^{1,2, *(\mathbb{D}, \text { Harold J. Hughes }}{ }^{1}$, Markus Keck ${ }^{3}$ and Daniela Sauer ${ }^{1}$ \\ 1 Department of Physical Geography, Institute of Geography, University of Göttingen, Goldschmidtstr. 5, \\ 37077 Göttingen, Germany; hhughes@uni-goettingen.de (H.J.H.); \\ Daniela.Sauer@geo.uni-goettingen.de (D.S.) \\ 2 Soils and Fertilizers Research Institute, Duc Thang, Bac Tu Liem, Hanoi 1000, Vietnam \\ 3 Department of Human Geography, Institute of Geography, University of Göttingen, Goldschmidtstr. 5, \\ 37077 Göttingen, Germany; markus.keck@geo.uni-goettingen.de \\ * Correspondence: hungdaotrongvn@gmail.com or trong-hung.dao@geo.uni-goettingen.de; \\ Tel.: +49-551-391-2708
}

Received: 18 February 2019; Accepted: 15 March 2019; Published: 19 March 2019

check for updates

\begin{abstract}
In Vietnam, approximately 39 million tons of rice (Oryza sativa) residues accrue every year. In this study, we quantified soil nutrient balances of paddy rice fields under different crop-residue management practices in northern Vietnam. On twelve farms, we calculated nutrient balances for the four prevalent rice-residue management practices, i.e., (1) direct incorporation of rice residues into the soil, (2) application of rice-residue compost, (3) burning of rice residues on the field, and (4) the use of rice residues as fodder for livestock. Soils under practices (1) to (3) showed a positive nutrient balance, which indicates that soil fertility can be maintained under these practices and that the amounts of chemical fertilizers can be considerably reduced. If not, there is a risk of eutrophication in the surrounding surface waterbodies. Practice (4), in contrast, resulted in a negative nutrient balance, which indicates the need for returning nutrients to the soils. From our findings we conclude that knowledge about the effects of rice-residue management practices on nutrient cycles may help to optimize the use of fertilizers, resulting in a more sustainable form of agriculture.
\end{abstract}

Keywords: paddy-rice farming; crop-residue management; nutrient balance; smallholders; fertilizer use; Vietnam

\section{Introduction}

Rice is the most important food crop in Asia. In Vietnam, annual rice consumption amounts to $150-200 \mathrm{~kg}$ per capita, providing $60 \%$ of protein and $50-70 \%$ of calories of the dietary intake [1]. Furthermore, Vietnam is one of the largest rice producers and exporters in the world. Ninety percent of the arable land in Vietnam is used for rice cultivation, which corresponds to 11.5 million ha, with a median landholding size of 0.65 ha [2]. As such, smallholders are the backbone of the country's agriculture.

The cultivation of rice involves the accruement of large amounts of straw and stalk. On average, one hectare of rice generates about five tons of residues, equaling to approximately 39 million tons per year [3]. The major portion of rice residues is burned on the field in Vietnam, like in many countries [4-6]. The burning of crop residues however results in a loss of nutrients, including the major macronutrients nitrogen $(\mathrm{N})$, phosphorus $(\mathrm{P})$, and potassium $(\mathrm{K})$ [7-10]. In contrast, incorporating crop residues into the soil can increase soil organic carbon (SOC) stocks, improve soil structure, and substantially contribute to maintaining appropriate levels of nutrients such as $\mathrm{N}, \mathrm{P}$, and $\mathrm{K}$ in the 
soil $[7,11,12]$. Incorporating crop residues into the soil has the potential to increase crop yields and reduce the need for chemical fertilizers. As such, crop residues may serve as a potential partial substitute for chemical fertilizers in agriculture [12-15]. Vietnam relies heavily on the import of chemical fertilizers. In the case of $\mathrm{K}$ fertilizers, $100 \%$ is imported. In 2017 , Vietnam imported 4.64 million tons of chemical fertilizers at an estimated cost of 1.23 billion US\$ [16]. From 1992 to 2015, the average amount of total N, P, and K fertilizers applied in agricultural production in Vietnam doubled. At the same time, fertilizer-use efficiency was low, resulting in the loss of several hundreds of millions of US dollars annually for the national economy, and causing eutrophication and greenhouse gas emissions [16-18]. Against this background, the increased use of readily available, cost-efficient, and domestically produced organic fertilizer, such as crop residues, may reduce the need for costly imported chemical fertilizer and improve the national trade balance $[19,20]$. This would also increase farmers' net income by reducing their investments for chemical fertilizers [19,21].

Soil nutrient balances are the overall net result of the various nutrient flows of a farming system [22,23]. Nutrient balances have been quantified in Africa and Asia [24-27]. However, these studies focused on urban agriculture and aquaculture, but not on rice-farming systems. Moreover, most of the studies were limited to one year of observation, thus capturing only short-term effects, which limits the possibility to quantify the main factors that control the element balances. In this study we analyzed the relationship between crop-residue management practices and nutrient flows in the soil-plant system in paddy rice fields of selected areas of northern Vietnam. The specific objectives were (i) to analyze agricultural inputs and outputs of $\mathrm{N}, \mathrm{P}$, and $\mathrm{K}$ in different crop-residue management systems, and (ii) to evaluate the obtained soil nutrient balances with respect to the prospective potential of partially substituting imported chemical fertilizers by rice residues. The overall aim of the study was thus to evaluate the potential of crop-residue management to contribute to a more sustainable agriculture in Vietnam in the future.

\section{Materials and Methods}

\subsection{Study Areas}

We selected two study areas in contrasting rice-production regions of northern Vietnam. One study area was in Luong Phong Commune (Hiep Hoa District, Bac Giang Province; $106^{\circ} 01^{\prime}$ E, $21^{\circ} 20^{\prime} \mathrm{N}$ ), $60 \mathrm{~km}$ East of Hanoi (Figure 1, bottom).

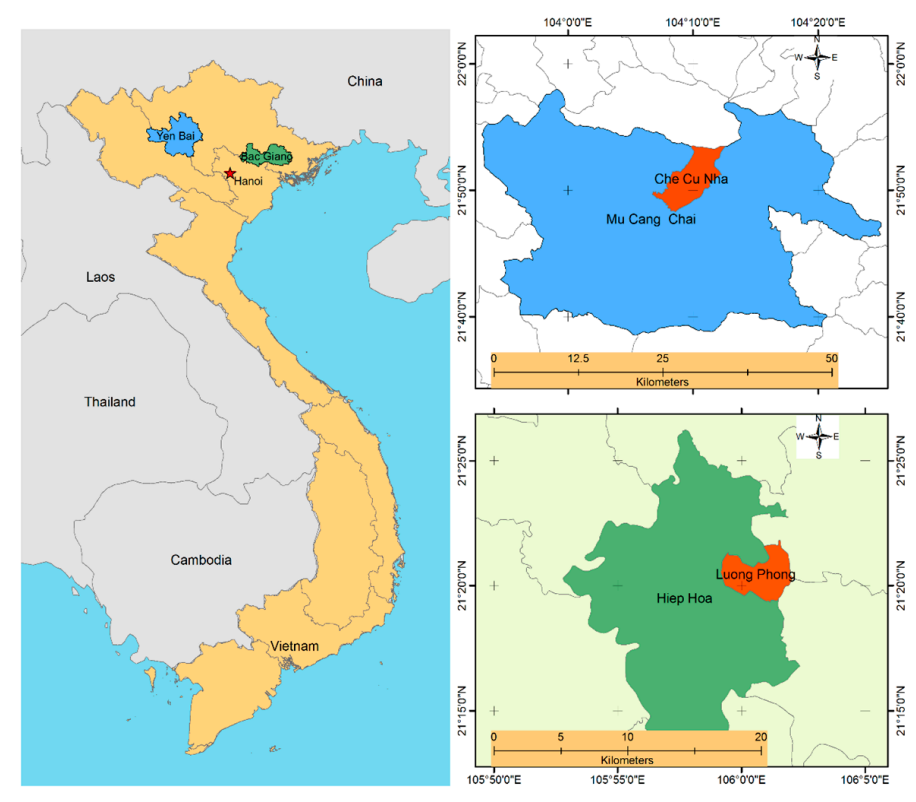

Figure 1. Study sites in northern Vietnam. 
It is characterized by a subtropical monsoon climate with a mean annual temperature of $23.5^{\circ} \mathrm{C}$ and mean annual rainfall of $1620 \mathrm{~mm}$, with more than $80 \%$ of the rainfall occurring between May and October. The soils are Plinthic Acrisols according to World Reference Base WRB (2014), corresponding to "gray degraded soils" in the Vietnamese soil classification. Acrisols are among the main soils used for agriculture in Vietnam, occupying 1.4 million hectares (4.5\% of the total land, and $12 \%$ of the agricultural land of Vietnam). In northern Vietnam, these soils are concentrated in Bac Giang, Vinh Phuc, Bac Ninh, Thai Nguyen Province, and Hanoi city, which are known for the most intensive agricultural production [28-30]. The texture of the soils is predominantly sandy loam. Their fertility is generally low [31].

The other study area was located in Che $\mathrm{Cu}$ Nha Commune (Mu Cang Chai District, Yen Bai Province; $104^{\circ} 10^{\prime} \mathrm{E}, 21^{\circ} 51^{\prime} \mathrm{N}$ ), $320 \mathrm{~km}$ Northwest of Hanoi (Figure 1, top). The climate there is humid-tropical with a mean annual temperature of $22.8^{\circ} \mathrm{C}$ and a mean annual precipitation of $1337 \mathrm{~mm}$, influenced by the Northeast monsoon. The average air moisture is $81 \%$. Maximum daytime temperature is $38-40{ }^{\circ} \mathrm{C}$, occurring in June and July, while minimum daytime temperature is $2-5^{\circ} \mathrm{C}$, occurring from December to February. The predominant soils are Stagnic Acrisols, and paddy rice is the major crop on these soils [32].

Incorporation of crop residues into the soils is a widespread practice in Luong Phong Commune (Bac Giang Province), accounting for 51\% of the total volume of crop residues. Another $38 \%$ of the crop residues are burned on the field, and about $10 \%$ are used as fodder for cattle [13]. The proportion of rice residues that are burned on the field is lower in Bac Giang Province than in Thai Binh Province [33] and in the Mekong Delta [5], where similar studies have been conducted. For comparison, in the Mekong Delta, $98 \%$ of the rice residues of the winter-spring season, $90 \%$ of rice residues of the summer-autumn season, and $54 \%$ of the rice residues of the autumn-winter season are burned. In Yen Bai Province, all crop residues are used as fodder for cattle.

\subsection{Characterization of the Cropping Systems}

The types of cropping systems that are common in a certain region depend on the climatological conditions, irrigation/precipitation patterns, and topography. Five cropping systems were identified in the two study areas (Table 1).

Table 1. General characteristics of the cropping systems in the two study areas.

\begin{tabular}{ccc}
\hline Characteristics & Luong Phong Commune & Che Cu Nha Commune \\
\hline Topography & Rainfed lowland paddy rice & Terraced paddy rice fields \\
Mean precipitation $(\mathrm{mm})$ & 1620 & 1337 \\
Water source & Irrigation & Rainfall \\
Cropping systems & $\begin{array}{c}\text { Spring rice-summer rice; spring } \\
\text { rice-summer rice-maize (sweat } \\
\text { potatoes) }\end{array}$ & $\begin{array}{c}\text { Summer rice; summer maize } \\
\text { grown on sloping land }\end{array}$ \\
\hline
\end{tabular}

In Luong Phong Commune (Bac Giang Province), spring rice is usually planted in February and harvested in late May. Summer rice is planted in late June and harvested in late December. Some farmers also plant maize and sweet potatoes in October that are harvested in January. Our study focused on the spring rice-summer rice cropping system only, because the farms that grow maize or sweat potatoes in the two study areas amounted to only $13 \%$ and $15 \%$ of the total number of farms, respectively. In Che $\mathrm{Cu}$ Nha Commune (Yen Bai Province), summer rice is planted in May and harvested in September. Maize is also planted in May but harvested in October [13]. 


\subsection{Monitoring of Element Balances}

We monitored quantitative nutrient inputs and outputs of each plot over two subsequent years. Based on the mentioned four types of rice residue management in the two study areas [13], we selected twelve farms for further in-depth analysis (Table 2).

Table 2. Rice-residue management in the study areas.

\begin{tabular}{cc}
\hline Study Area & Rice-Residue Management \\
\hline $\begin{array}{c}\text { Luong Phong Commune } \\
\text { (Bac Giang Province) }\end{array}$ & $\begin{array}{c}\text { Complete rice-residue incorporation before transplanting of spring } \\
\text { Luong Phong Commune } \\
\text { (Bac Giang Province) }\end{array}$ \\
$\begin{array}{c}\text { Luong Phong Commune } \\
\text { (Bac Giang Province) }\end{array}$ & $\begin{array}{c}\text { Application of composted rice residues before transplanting of } \\
\text { spring rice (compost 1) and summer rice (compost 2) }\end{array}$ \\
$\begin{array}{c}\text { Che Cu Nha Commune } \\
\text { (Yen Bai Province) }\end{array}$ & Application of ash from burned rice residues before transplanting of \\
spring rice (burn 1) and summer rice (burn 2)
\end{tabular}

We collected data on rice-residue management practices from September 2015 to September 2017. For this purpose, we established nine plots in Luong Phong Commune (Bac Giang Province), including the following practices: (1) Incorporation of crop residues into the soil, (2) application of composted rice residues, (3) application of ash from burned rice residues. In addition, we established three plots in $\mathrm{Che} \mathrm{Cu}$ Nha Commune (Yen Bai Province), where all rice residues were collected and used as fodder for cattle. For each of the plots, the exact amounts of inputs (i.e., fertilizers, crop residues, manure, and ash) and outputs (harvested crops) were recorded for each crop season. After harvest, we analyzed nutrient concentrations of rice grains, rice residues, manure, and soils. The composition of the chemical fertilizers was provided by the manufacturers. Nutrient fluxes through rain, irrigation, ash, $\mathrm{N}$ fixation, leaching, and volatilization were estimated based on the data of references $[7,34,35]$.

\subsection{Sampling and Analysis}

Samples of topsoil, crop residues, rice grains, chemical fertilizers, and manure were collected at all plots, to monitor element fluxes of the four types of rice residue management, with three replicates per management practice (Figure 2).

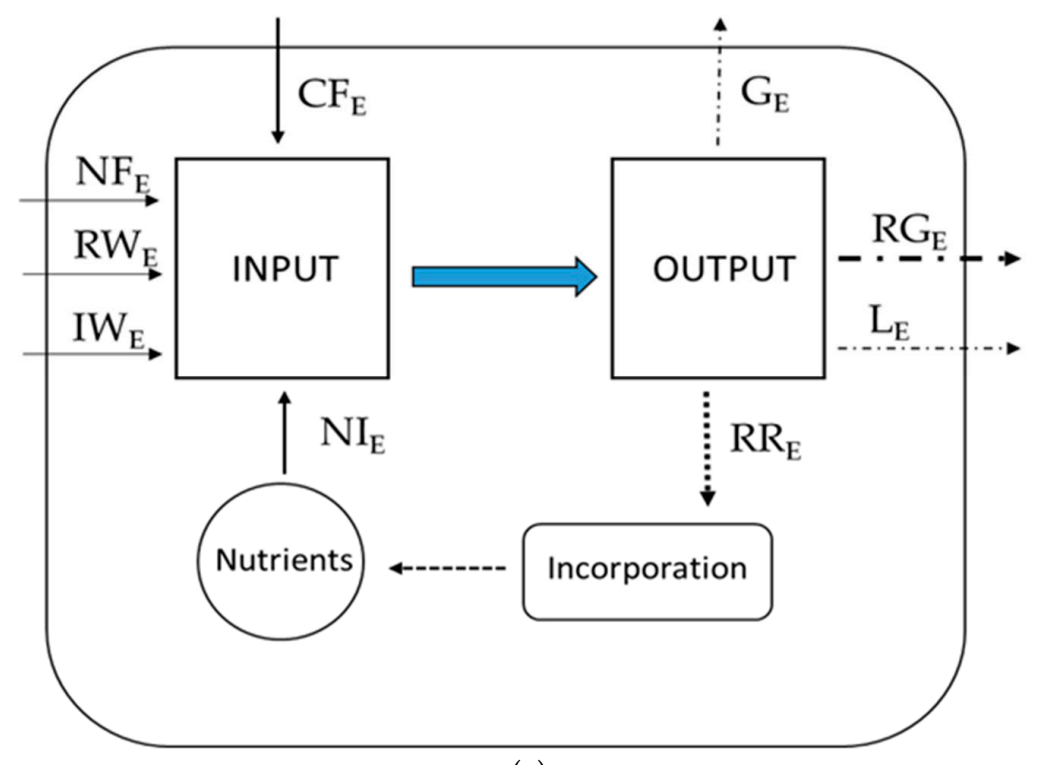

(a)

Figure 2. Cont. 


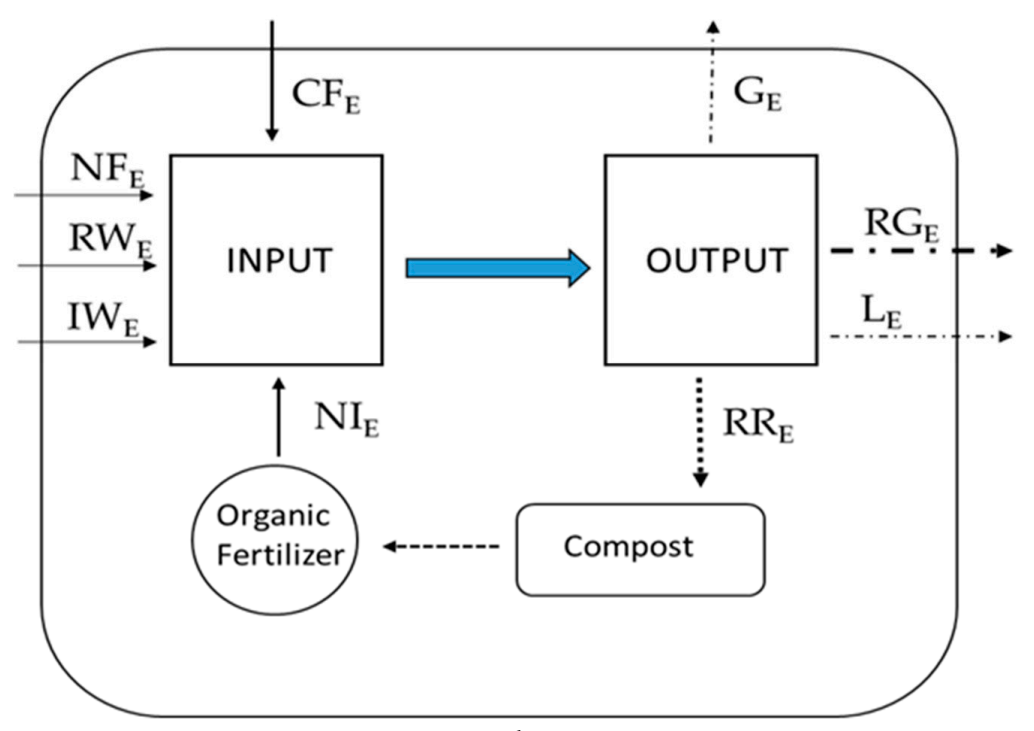

(b)

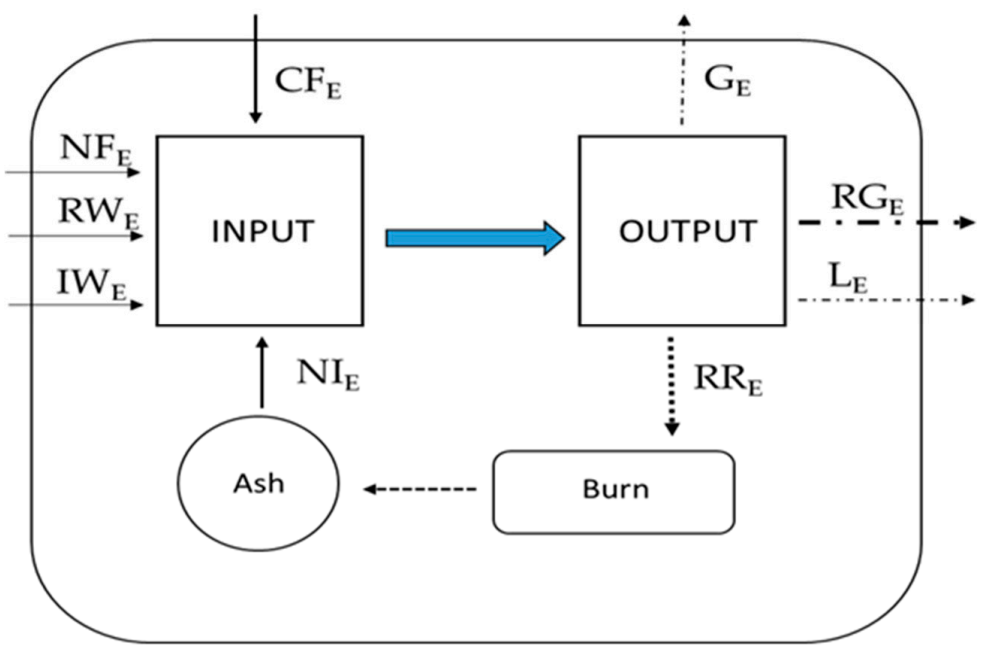

(c)

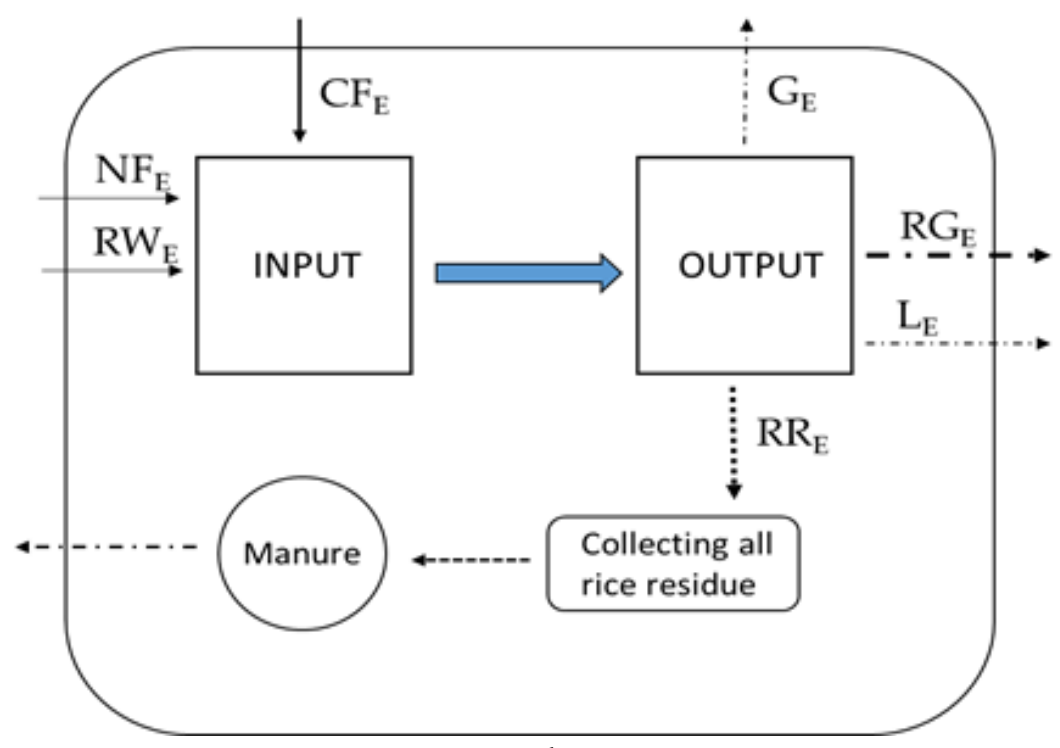

(d)

Figure 2. Schematic representation of nutrient fluxes in the four types of rice-residue management practices. $\mathrm{CF}_{\mathrm{E}}$ : Chemical fertilizers; $\mathrm{G}_{\mathrm{E}}$ : Gaseous losses of $\mathrm{N} ; \mathrm{RR}_{\mathrm{E}}$ : Rice residues; $\mathrm{NF}_{\mathrm{E}}$ : Nitrogen fixation; $\mathrm{RG}_{\mathrm{E}}$ Harvested rice grain; $\mathrm{RW}_{\mathrm{E}}$ : Rain water; $\mathrm{L}_{\mathrm{E}}$ : Leaching; $\mathrm{IW}_{\mathrm{E}}$ : Irrigation water; $\mathrm{NI}_{\mathrm{E}}$ : Nutrients input as rice residue incorporation, compost or ash; (a) incorporation of rice residues into the soil; (b) application of rice-residue compost; (c) application of ash from burned rice residues; (d) collection of all rice residues for use as fodder for cattle. 
The topsoils were sampled at a $0-20 \mathrm{~cm}$ depth, using a stainless-steel trowel. Five topsoil samples, taken within an area of $5 \mathrm{~m} \times 5 \mathrm{~m}$, were mixed in the field. Samples of crop residues and rice grains were collected at the time of harvesting from an area of $2 \mathrm{~m} \times 2 \mathrm{~m}$ within the area from which topsoil samples had been taken. The crop residues were weighed. Subsamples for chemical analysis were air-dried, cut into small pieces, dried at $60-70{ }^{\circ} \mathrm{C}$ to constant weight, and ground to pass a $0.4 \mathrm{~mm}$ nylon sieve. Samples of chemical fertilizers and manure were collected either from the fields or obtained from the farm households. The samples were air-dried, ground, and sieved for chemical analysis. Nutrient analysis was carried out at the laboratory of the Soils and Fertilizers Research Institute (SFRI) in Hanoi, Vietnam. Soil $\mathrm{pH}\left(\mathrm{KCl}\right.$ and $\left.\mathrm{H}_{2} \mathrm{O}\right)$ was measured at a soil: solution ratio of 1:5, using a pH electrode (ISO 10390: 2005). Concentrations of total organic carbon were determined by the Walkey-Black method (ISO-22003: 2008), and concentrations of total $\mathrm{N}$ were analyzed by semi-micro-Kjeldahl (ISO 11261: 1995). The available P was extracted by the Bray 2 method and analyzed colorimetrically (by use of the vanadomolybdophosphoric acid colorimetric method). The total contents of $\mathrm{P}$ and $\mathrm{K}$ were analyzed after digestion with $\mathrm{H}_{2} \mathrm{SO}_{4}+\mathrm{HNO}_{3}(1: 1, v: v)$. The total contents of $\mathrm{P}$ were determined colorimetrically, and those of $\mathrm{K}$ were determined by using a photoelectric flame photometer (Corning 410-UK). The texture was analyzed using the sieve and pipette method, and particle density was determined by use of a pycnometer (ISO 11277:2009). Cation exchange capacity (CEC) was determined using ammonium acetate at $\mathrm{pH} 7$.

\subsection{Calculation of Nutrient Balances}

Nutrient balances of N, P, and K were calculated as the difference between inputs and outputs. Changes in soil nutrient status were evaluated using the following element balance equation $[24,26]$ :

$$
\Delta P_{E}=I_{E}-O_{E}
$$

where $\Delta P_{E}$ represents changes in the soil pool, $I_{E}$ comprises all inputs, and $O_{E}$ includes all outputs of the element $E$. Element inputs $I_{E}$ considered in this study were through irrigation water from rivers $I W_{E}$, rainwater $R W_{E}$, chemical fertilizers $C F_{E}$, nutrient input as rice residue incorporation, compost or ash $N I_{E}$, and biological $N_{2}$ fixation $N_{E}$. Considered element outputs $O_{E}$ were through harvested rice grain $R G_{E}$, rice residues $R R_{E}$, gaseous losses of nitrogen $G_{E}$, and leaching $L_{E}$. The net changes in the soils' stocks of the element $\mathrm{E} \Delta \mathrm{Soil}_{E}$ were calculated as:

$$
\Delta \operatorname{Soil}_{E}=\left(I W_{E}+R W_{E}+C F_{E}+N I_{E}+N_{E}\right)-\left(R G_{E}+R R_{E}+G_{E}+L_{E}\right)
$$

\subsection{Statistical Analysis}

A one-way ANOVA was performed to test the significance of the effects of applying chemical fertilizer, rice residues, compost, and ash at the two study sites. Significance was defined as $p<0.05$ using the Duncan test.

\section{Results}

The soils of the investigated farms in Luong Phong Commune (Bac Giang Province) were characterized by low fertility (Table 3 ).

They had low $\mathrm{pH}$ (average $\mathrm{pH} \mathrm{KCl}=4.5$ ) and light textures, typically varying from sand to silt. They showed low CEC and low concentrations of SOC, N, and K, but high contents of plant-available $\mathrm{P}$. The soils were highly porous, making soil preparation easy $[30,36]$. The fields were in flat topography with shallow groundwater that is readily exploitable for irrigation [13]. Soils of the farms in Che $\mathrm{Cu}$ Nha Commune (Yen Bai Province) were even somewhat more acidic (average $\mathrm{pH} \mathrm{KCl}=4.0$ ). They had a heavier texture (33\% clay), higher CEC $\left(13.9 \mathrm{cmolc} \mathrm{kg}^{-1} \mathrm{CEC}\right)$, and higher total nutrient contents,

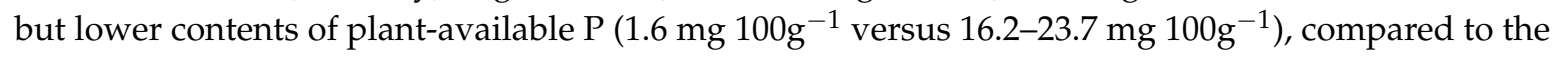
soils of Luong Phong Commune. 
Table 3. Topsoil (0-20 cm depth) characteristics under four rice-residue management practices.

\begin{tabular}{|c|c|c|c|c|}
\hline \multirow[t]{3}{*}{ Parameter } & \multicolumn{4}{|c|}{ Rice-Residue Management } \\
\hline & \multicolumn{3}{|c|}{ Luong Phong } & \multirow{2}{*}{$\begin{array}{c}\text { Che Cu Nha } \\
\text { Collect }\end{array}$} \\
\hline & Incorporation & Compost & Burn & \\
\hline $\mathrm{pH}(\mathrm{KCL})$ & $4.50(0.50)$ & $4.70(0.40)$ & $4.60(0.40)$ & $4.00(0.10)$ \\
\hline $\mathrm{pH}\left(\mathrm{H}_{2} \mathrm{O}\right)$ & $5.10(0.40)$ & $5.20(0.50)$ & $5.30(0.50)$ & $4.90(0.20)$ \\
\hline Bulk density $\left(\mathrm{g} \mathrm{cm}^{-3}\right)$ & $1.31(0.09)$ & $1.35(0.03)$ & $1.33(0.10)$ & $1.11(0.05)$ \\
\hline Coarse sand (\%) & $2.50(1.90)$ & $0.50(0.10)$ & $2.60(2.10)$ & $3.90(1.80)$ \\
\hline Fine sand $(\%)$ & $62.9(13.6)$ & $57.8(8.00)$ & $54.7(0.80)$ & $31.5(7.90)$ \\
\hline Silt (\%) & $21.9(2.80)$ & $32.0(5.80)$ & $31.5(1.40)$ & $31.4(9.40)$ \\
\hline Clay (\%) & $12.7(8.80)$ & $9.70(2.30)$ & $11.2(1.40)$ & $33.2(12.30)$ \\
\hline $\mathrm{CEC}\left(\mathrm{cmol}_{\mathrm{C}} \mathrm{kg}^{-1}\right)$ & $6.77(2.03)$ & $8.30(3.39)$ & $6.71(1.99)$ & $13.90(3.04)$ \\
\hline $\mathrm{SOC}\left(\mathrm{g} \mathrm{kg}^{-1}\right)$ & $1.30(0.33)$ & $1.26(0.20)$ & $1.25(0.15)$ & $1.50(0.51)$ \\
\hline Total N $\left(\mathrm{g} \mathrm{kg}^{-1}\right)$ & $0.12(0.03)$ & $0.12(0.02)$ & $0.12(0.03)$ & $0.14(0.04)$ \\
\hline Total P $\left(\mathrm{g} \mathrm{kg}^{-1}\right)$ & $0.05(0.02)$ & $0.06(0.02)$ & $0.05(0.01)$ & $0.10(0.03)$ \\
\hline Total K $\left(\mathrm{g} \mathrm{kg}^{-1}\right)$ & $0.03(0.03)$ & $0.05(0.02)$ & $0.03(0.02)$ & $0.40(0.13)$ \\
\hline Available P (mg $100 g^{-1}$ soil) & $16.74(4.02)$ & $23.74(11.81)$ & $16.15(3.76)$ & $1.64(0.82)$ \\
\hline Available K (mg 100g ${ }^{-1}$ soil) & $3.78(2.29)$ & $4.33(1.99)$ & $2.93(0.72)$ & $8.43(0.96)$ \\
\hline Total N stock $\left(\mathrm{t} \mathrm{ha}^{-1}\right)$ & 3.14 & 3.24 & 3.19 & 3.11 \\
\hline Total P stock (t ha $\left.{ }^{-1}\right)$ & 1.31 & 1.62 & 1.33 & 2.22 \\
\hline Total K stock (t ha ${ }^{-1}$ ) & 0.79 & 1.35 & 0.80 & 8.88 \\
\hline
\end{tabular}

Note: Numbers represent means (standard deviation) of selected soil properties over the 24 months of monitoring $(n=6-9)$.

Nutrient inputs were mainly through chemical fertilizers, rice-residue compost, and rice residues. The use of chemical fertilizers in the intensive rice-cropping systems of Luong Phong Commune exceeded the recommendations by the Agriculture Extension Department [37,38]. N inputs through chemical fertilizers were higher for the burning plots and incorporation plots than for the other plots (Table 4).

Table 4. Mean N, P, and K inputs from chemical fertilizers at plot level.

\begin{tabular}{ccccccc}
\hline Rice Residue & \multicolumn{3}{c}{ Spring Rice (kg ha ${ }^{-\mathbf{1}}$ ) } & \multicolumn{3}{c}{ Summer Rice (kg ha $\left.{ }^{-\mathbf{1}}\right)$} \\
\cline { 2 - 7 } Management & $\mathbf{N}$ & $\mathbf{P}$ & $\mathbf{K}$ & $\mathbf{N}$ & $\mathbf{P}$ & $\mathbf{K}$ \\
\hline Incorporation & $114.21^{\mathrm{c}}$ & $28.09^{\mathrm{bc}}$ & $97.79^{\mathrm{bc}}$ & $101.01^{\mathrm{abc}}$ & $32.66^{\mathrm{c}}$ & $75.99^{\mathrm{b}}$ \\
Compost & $86.11^{\mathrm{a}}$ & $24.82^{\mathrm{ab}}$ & $81.46^{\mathrm{b}}$ & $88.59^{\mathrm{ab}}$ & $21.29^{\mathrm{a}}$ & $86.34^{\mathrm{b}}$ \\
Burning & $96.67^{\mathrm{abc}}$ & $27.40^{\mathrm{bc}}$ & $125.11^{\mathrm{cd}}$ & $109.26^{\mathrm{cb}}$ & $31.94^{\mathrm{bc}}$ & $132.95^{\mathrm{d}}$ \\
Collect & 0 & 0 & 0 & $96.66^{\mathrm{abc}}$ & $20.29^{\mathrm{a}}$ & $12.27^{\mathrm{a}}$ \\
\hline
\end{tabular}

Note: $\mathrm{a}, \mathrm{b}, \mathrm{c}$, and d represent data that are statistically different $(p<0.05)$.

Nevertheless, the burning plots showed a negative $\mathrm{N}$ balance for spring rice (Figure 3). 


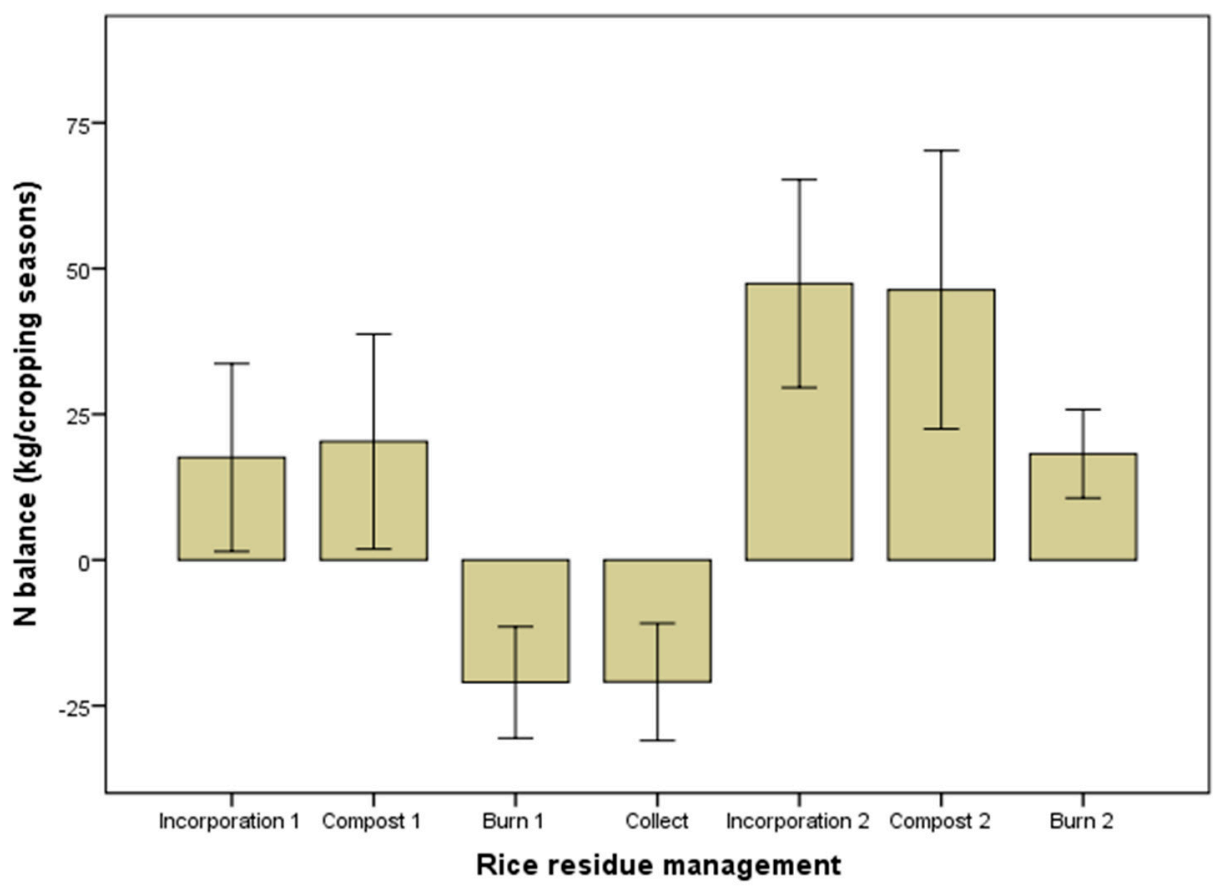

Figure 3. Mean balance of $\mathrm{N}$ per cropping season under the selected rice-residue management practices. The columns show arithmetic means $(n=6)$ and the bars represent standard deviations.

The burning plots received the highest total $\mathrm{K}\left(125 / 133 \mathrm{~kg} \mathrm{ha}^{-1}\right)$ and P inputs $\left(27 / 32 \mathrm{~kg} \mathrm{ha}^{-1}\right)$ through chemical fertilization of spring and summer rice, respectively. $\mathrm{K}$ and $\mathrm{P}$ inputs to the compost and incorporation plots were high, too, leading to positive K and P balances (Figures 4 and 5).

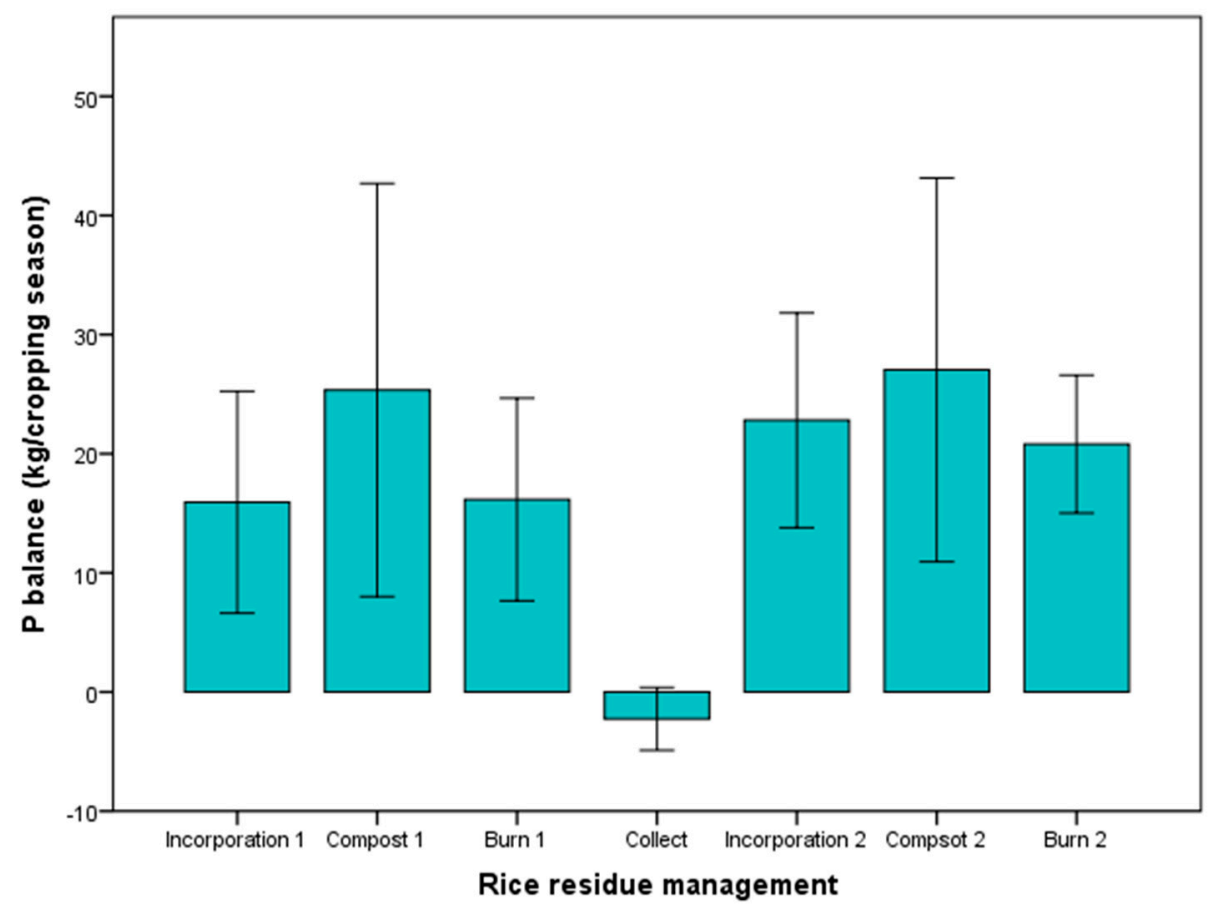

Figure 4. Mean balance of $P$ per cropping season under the selected rice-residue management practices. The columns show arithmetic means $(n=6)$ and the bars represent standard deviations. 


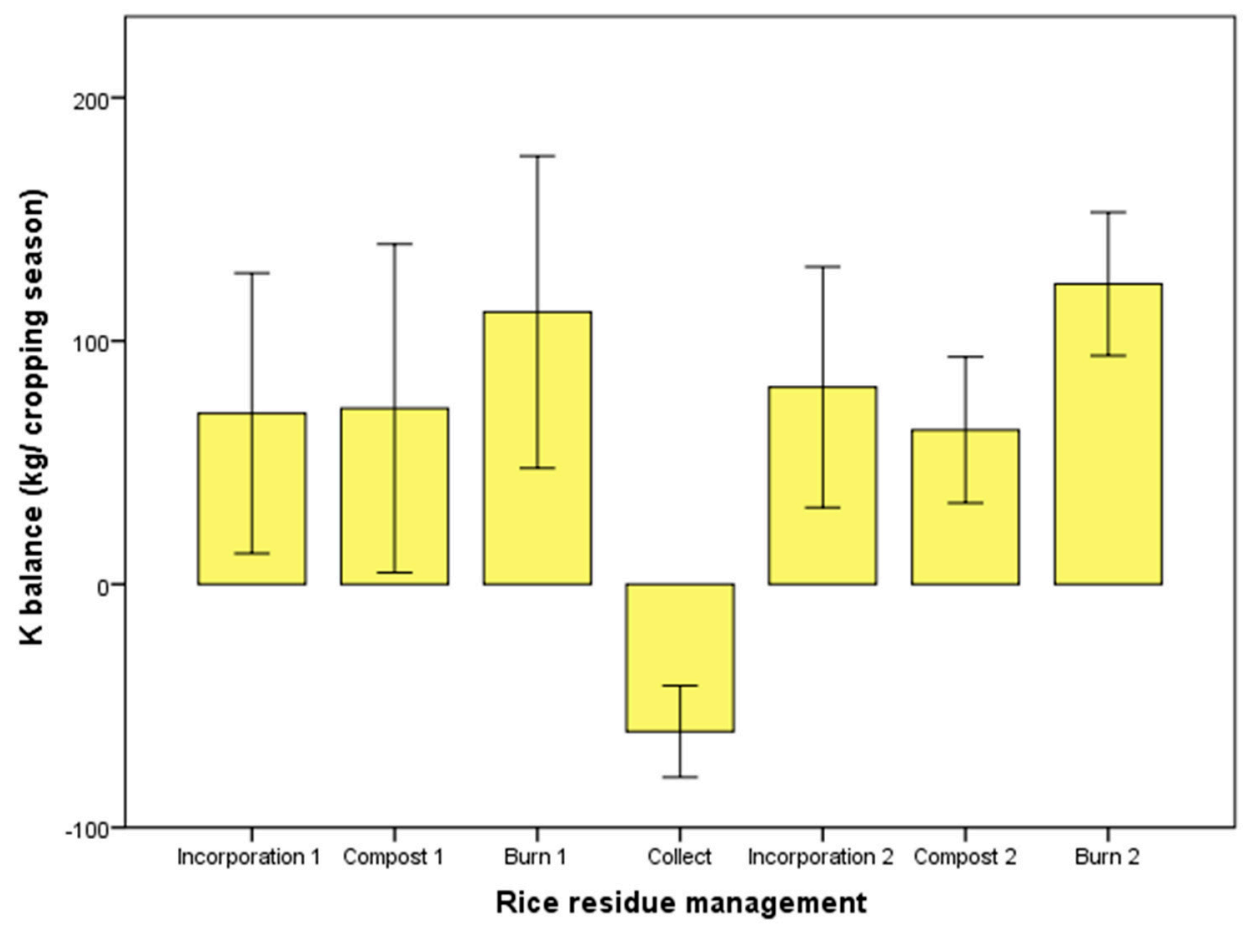

Figure 5. Mean balance of K per cropping season under the selected rice-residue management practices. The columns show arithmetic means $(n=6)$ and the bars represent standard deviations.

In contrast, nutrient inputs through chemical fertilizers were lowest in collection plots in the $\mathrm{Che} \mathrm{Cu}$ Nha Commune, especially for K. Fertilizer application in the collection plots in Che Cu Nha Commune did not match the nutrient requirements of the rice, which resulted in negative $\mathrm{N}, \mathrm{P}$, and $\mathrm{K}$ balances for these plots (Figures 3-5).

Additional nutrient inputs through the different rice-residue management practices differed considerably. For the compost and incorporation plots, their contributions to the total nutrient inputs amounted to $21-35 \% \mathrm{~N}, 20-53 \% \mathrm{P}$, and $29-45 \% \mathrm{~K}$ (Table 5).

Table 5. Mean N, P, and K inputs from the incorporation of rice residues into the soils, application of compost from rice residues, and burning of rice residues at plot level.

\begin{tabular}{cccccccccc}
\hline \multirow{2}{*}{ Rice Residue Management } & \multicolumn{3}{c}{ Spring Rice (kg/ha) } & \multicolumn{3}{c}{ Summer Rice (kg/ha) } \\
\cline { 2 - 9 } & $\mathbf{C}$ & $\mathbf{N}$ & $\mathbf{P}$ & $\mathbf{K}$ & $\mathbf{C}$ & $\mathbf{N}$ & $\mathbf{P}$ & $\mathbf{K}$ \\
\hline Incorporation & $2057^{\mathrm{c}}$ & $31^{\mathrm{b}}$ & $8^{\mathrm{a}}$ & $34^{\mathrm{a}}$ & $2246^{\mathrm{d}}$ & $42^{\mathrm{c}}$ & $8^{\mathrm{a}}$ & $61^{\mathrm{b}}$ \\
Compost & $788^{\mathrm{b}}$ & $46^{\mathrm{c}}$ & $19^{\mathrm{b}}$ & $48^{\mathrm{ab}}$ & $831^{\mathrm{b}}$ & $44^{\mathrm{c}}$ & $24^{\mathrm{c}}$ & $35^{\mathrm{a}}$ \\
Burning & $53^{\mathrm{a}}$ & $0^{\mathrm{a}}$ & $7^{\mathrm{a}}$ & $46^{\mathrm{a}}$ & $56^{\mathrm{a}}$ & $0^{\mathrm{a}}$ & $7^{\mathrm{a}}$ & $45^{\mathrm{a}}$ \\
\hline
\end{tabular}

Note: $\mathrm{a}, \mathrm{b}, \mathrm{c}, \mathrm{d}$ represent data that are statistically different $(p<0.05)$.

For the collection plots (where rice residues were collected to feed cattle), all management-related nutrient inputs were calculated as $0 \mathrm{~kg} \mathrm{ha}^{-1}$ per cropping season. For the burning plots, only the management-related $\mathrm{N}$ inputs were calculated as $0 \mathrm{~kg} \mathrm{ha}^{-1}$ (accounting for gaseous loss of $\mathrm{N}$ through burning of the crop residues), whereas the management-related $\mathrm{K}$ inputs to the burning plots (45-46 $\mathrm{kg} \mathrm{ha}^{-1}$ per cropping season) were similar to those of the compost plots (35-48 $\mathrm{kg} \mathrm{ha}^{-1}$ ) and incorporation plots (34-61 kg ha $\left.{ }^{-1}\right)$. Compost application was associated with the largest management-related $\mathrm{P}\left(19-24 \mathrm{~kg} \mathrm{ha}^{-1}\right)$ and $\mathrm{N}\left(44-46 \mathrm{~kg} \mathrm{ha}^{-1}\right)$ inputs per cropping season.

$\mathrm{C}$ inputs per cropping season related to the different management practices decreased in the following order: Incorporation of rice residues $\left(\sim 2.1-2.2 \mathrm{t} \mathrm{ha}^{-1}\right)>$ application of compost from rice 
residues $\left(788-831 \mathrm{~kg} \mathrm{ha}^{-1}\right)>$ burning of rice residues $\left(53-56 \mathrm{~kg} \mathrm{ha}^{-1}\right)$, whereby total $\mathrm{C}$ loss through crop-residue burning was high $\left(\sim 2.0-2.1 \mathrm{t} \mathrm{ha}^{-1}\right)$.

For the collection plots in the $\mathrm{Che} \mathrm{Cu}$ Nha Commune, all nutrient balances were negative, amounting to $-21 \mathrm{~kg} \mathrm{ha}^{-1} \mathrm{a}^{-1}$ for $\mathrm{N},-3 \mathrm{~kg} \mathrm{ha}^{-1} \mathrm{a}^{-1}$ for $\mathrm{P}$, and $-60 \mathrm{~kg} \mathrm{ha}^{-1} \mathrm{a}^{-1}$ for $\mathrm{K}$. The other three management practices on the plots in Luong Phong Commune generally led to positive nutrient balances, whereby the surplus of $\mathrm{N}$ was $18-47 \mathrm{~kg} \mathrm{ha}^{-1} \mathrm{a}^{-1}$, that of $\mathrm{P}$ was $16-27 \mathrm{~kg} \mathrm{ha}^{-1} \mathrm{a}^{-1}$, and that of $\mathrm{K}$ was $63-123 \mathrm{~kg} \mathrm{ha}^{-1} \mathrm{a}^{-1}$. The only exception was spring rice with burning of crop residues (Burn 1 in Figure 3), which resulted in a negative $\mathrm{N}$ balance.

\section{Discussion}

\subsection{Effects of Rice-Residue Management on Nutrient Balances of Rice-Cropping Systems}

This study showed that considerable amounts of nutrients in paddy-rice systems can be recycled within the system through appropriate rice-residue management. Direct incorporation of the rice residues into the soils after harvest returned $31-42 \mathrm{~kg} \mathrm{~N} \mathrm{ha}^{-1}, 8 \mathrm{~kg} \mathrm{P} \mathrm{ha}^{-1}$, and $34-61 \mathrm{~kg} \mathrm{~K}^{-1}$ per cropping season to the soil. Application of rice-residue compost returned significantly more $\mathrm{P}$ and somewhat more $\mathrm{N}$ to the soils, whereas the amounts of recycled $\mathrm{K}$ were similar in both management practices. In detail, compost application in our study involved the return of $44-46 \mathrm{~kg} \mathrm{~N} \mathrm{ha}^{-1}$, 19-24 kg P ha ${ }^{-1}$, and 35-48 $\mathrm{kg} \mathrm{K} \mathrm{ha}^{-1}$ per cropping season to the soil. Thus, compared to the two other rice-residue management practices investigated in this study, burning and use as fodder for cattle, the two management practices (1) application of rice-residue compost and (2) direct rice-residue incorporation into the soils after harvest can considerably reduce the need of chemical fertilizers in paddy-rice cultivation $[13,14]$. In addition, high amounts of $C$ were also added to the soils through the incorporation of rice residues (2.1-2.2 $\mathrm{tC} \mathrm{ha}^{-1}$ per cropping season) and rice-residue compost (788-831 kg C ha-1 per cropping season). Thus, compared to burning (adding 53-56 kg C ha-1 per cropping season) or use as fodder (not calculated in this study), incorporation of rice residues and rice-residue compost may also increase SOC contents of paddy soils. The combined effect of nutrient cycling and SOC accumulation associated with these two practices has the potential to enhance soil quality $[39,40]$, ensure appropriate plant nutrition, and correspondingly high crop yields, and at the same time reduce the use of chemical fertilizers. In this way, these practices may contribute to an economically and ecologically more sustainable food-crop production. Thus, they can help to meet the food demands of a growing population [41-43]. In contrast, several studies have shown that burning of crop residues can result in a loss of almost $100 \% \mathrm{~N}, 25 \% \mathrm{P}$, and $20 \% \mathrm{~K}$ from the system [7,10]. Applying these figures to the situation of our study, we estimate that the practice of burning rice residues on the field, resulted in nutrient returns of about $0 \mathrm{~kg} \mathrm{~N} \mathrm{ha}^{-1}, 7 \mathrm{~kg} \mathrm{P} \mathrm{ha}^{-1}$, and $46 \mathrm{~kg} \mathrm{~K} \mathrm{ha}^{-1}$ to the soil per season. As no or very little $\mathrm{N}$ is returned from rice residues to the soil under the practice of crop-residue burning, large amounts of chemical $\mathrm{N}$ fertilizers are required under this management. The negative $\mathrm{N}$ balance, which we identified for spring rice cultivation on the burning plots of our study, points to this problem. In Che Cu Nha Commune (Yen Bai Province), as well in the upland areas of rice cultivation in Vietnam, removal of rice residues is the most common management practice at present. The rice residues are used as fodder for cattle. Farmers then collect the manure of their cattle and produce compost out of it. The compost is, however, not returned to the rice fields but is applied to maize fields. This practice leads to the loss of nutrients from the rice fields. Our results suggest that this loss is much greater for $\mathrm{K}$ than for $\mathrm{P}$, as shown by the comparison of the $\mathrm{K}$ and $\mathrm{P}$ balances of the collect plots in Figures 4 and 5. This outcome of our study agrees with the data reported by the authors in reference [34].

The $\mathrm{K}$ balance was positive for all rice-residue management practices except for the collection of the rice residues to feed cattle (Figure 5). This result is a consequence of the considerable amounts of $\mathrm{K}$ that were returned to the soils through the three other rice-residue management practices, direct incorporation, compost application, and burning. The amounts of $K$ that were returned through these 
three practices were in the same order of magnitude, amounting to $34-61 \mathrm{~kg} \mathrm{~K}^{-1} \mathrm{H}^{-1}$ per cropping season. It can be concluded that these three rice-residue management practices all are suitable for maintaining a high $\mathrm{K}$ use efficiency in rice-cropping systems.

In addition, the $\mathrm{P}$ balance was positive for all rice-residue management practices except for the collection of rice residues to feed cattle (Figure 4). The greatest positive P balance was obtained for the plots with compost application, although less chemical $\mathrm{P}$ fertilizers were used on these plots (21-25 $\mathrm{kg} \mathrm{P}^{-1}$ per cropping season), compared to the incorporation and burning plots (27-33 $\mathrm{kg} \mathrm{P} \mathrm{ha}^{-1}$ per cropping season). This large $\mathrm{P}$ surplus resulted from the high quantities of $\mathrm{P}$ that were returned to the soils through the compost (19-24 $\mathrm{kg} \mathrm{P} \mathrm{ha}^{-1}$ per cropping season), compared to the amounts of $\mathrm{P}$ that were returned through the direct incorporation of rice residues $\left(8 \mathrm{~kg} \mathrm{P} \mathrm{ha}^{-1}\right.$ per cropping season) or burning ( $7 \mathrm{~kg} \mathrm{P} \mathrm{ha}^{-1}$ per cropping season). It can be concluded that, among the investigated management practices, compost application has the greatest potential to increase $\mathrm{P}$ use efficiency in rice-cropping systems.

In general, organic fertilizers have been recognized as an important source of nutrients. In addition to the nutrients $\mathrm{N}, \mathrm{P}$, and $\mathrm{K}$ that were in the focus of this study, organic fertilizers also supply other macro- and micronutrients that are not contained in commercial chemical NPK fertilizers [34,44]. Moreover, organic fertilizers help improving soil fertility by increasing CEC and SOC contents. Farmers in Vietnam have used organic fertilizers for a long time [45,46], whereby the amounts and application methods vary between regions as well as between individual farms, depending on crops, soils, and available types of manure. Bui [44] reported that farmyard manure was usually applied before crop planting. The amounts of applied manure varied between $9.7 \mathrm{t} \mathrm{ha}^{-1}$ and $14.9 \mathrm{t} \mathrm{ha} \mathrm{a}^{-1}$, differing between individual households. However, these data on manure application were collected two decades ago. In more recent surveys [20,45] a decreased application of manure was found. This decline is related to (1) a decrease in the availability of manure from pig farms, because most of the pig manure in northern Vietnam is nowadays used for biogas production, (2) insufficient knowledge of farmers about the management of manure in an efficient and at the same time environmentally sustainable way [47], and (3) the ready availability of chemical fertilizers that seem to provide an easy substitution of manure [48].

Results of recent investigations by the authors of references [20,42], and ourselves (obtained 2015, unpublished), showed that farmers would prefer to apply more organic fertilizers, especially to rice, maize, and peanuts, but that the amounts of organic fertilizers produced on their own farms is not enough to supply their fields. In all three provinces, where these studies were carried out, no or low application of organic fertilizers to rice was found. This trend was due to an increase in the practice of burning harvest residues, lack of labor force, and reduction of livestock per hectare in the course of specialization of rice farms. $\mathrm{Vu}$ [45] and Hoang [42] identified logistic constraints (workload, volume of manure, distance to field, availability of labor force) as the most important reasons why the majority of farmers hesitated to apply manure to crops. Most of the farmers knew about the benefits of organic fertilizers for crop yield and soil fertility. However, the effects of crop-residue incorporation into soils on plant yield and its potential for partial fertilizer substitution were less known [13].

The outcomes of our study supported previous investigations, which suggested that rice-residue incorporation into soils can reduce the required amounts of fertilizers and therefore the costs related to the purchase of fertilizers [13,42]. In addition, it has the potential to increase SOC contents of soils, thus positively affecting soil physical, chemical, and biological properties. Our study under laid these assumptions through quantitative data. In conclusion, we propose that rice-residue incorporation into soils can be a suitable alternative management practice for farms that do not produce sufficient amounts of farmyard manure [14,15].

\subsection{Environmental Risks Related to Nutrient Management in Paddy-Rice Cultivation}

Our analysis showed that the total application of N, P, and K through chemical fertilizers and organic materials (rice residues, compost) to the soils was high (Tables 4 and 5), leading to 
a considerable surplus of these nutrients in the soils (Figures 3-5). The continued accumulation of excessive $\mathrm{N}, \mathrm{P}$, and $\mathrm{K}$ in rice-cropping systems involves a risk of nutrient leaching and potential eutrophication of adjacent surface-water bodies and groundwater $[25,26,49]$. The risk of eutrophication is particularly high in regions with paddy-rice cultivation, as the nutrient pathways from over fertilized soils to surface- and groundwater are extremely short and straightforward in paddy-rice systems. In the context of eutrophication, $\mathrm{P}$ deserves particular attention. Plinthic Acrisols, which are widely used for rice cultivation in Vietnam, and on which this study was performed, are generally considered infertile because of $\mathrm{P}$ fixation, low $\mathrm{pH}$ and $\mathrm{CEC}$, advanced stage of nutrient leaching, and consequently low nutrient contents [50,51]. Compared to the low P contents reported by Mi [51], in our study, we found increased contents of plant-available $\mathrm{P}$ in the soils, especially with compost application (Table 3). An increase was also reported in other studies [30,36]. Therefore, due to the high risk of eutrophication related to paddy-rice cultivation, application of $\mathrm{P}$, both in chemical and organic form, requires particular caution.

Another environmental aspect related to crop-residue management is the emission of fine ash particles from burning crop residues into the atmosphere. These emissions do not only affect the climate, but they also threaten human health in rural communities, as they may cause severe respiratory diseases [52,53]. For instance, burning one ton of rice straw releases $3 \mathrm{~kg}$ of particulate matter, $60 \mathrm{~kg}$ of $\mathrm{CO}, 1460 \mathrm{~kg}$ of $\mathrm{CO}_{2}, 2 \mathrm{~kg}$ of $\mathrm{SO}_{2}$, and $199 \mathrm{~kg}$ of ash [4]. In our study, the average amount of rice residues in Luong Phong Commune (Bac Giang Province) was 5.3-5.6 tha ${ }^{-1}$ per cropping season. Thus, burning the rice residues on all study plots in Luong Phong Commune would release 7.7-8.2 tons of $\mathrm{CO}_{2}$. This $\mathrm{CO}_{2}$ release also clearly exceeds the $\mathrm{CO}_{2}$ release from the decomposition of incorporated rice residues [54], which is relevant in the context of greenhouse-gas balances of rice-cultivation systems.

This study in which we established nutrient balances for paddy-rice fields under different rice-residue management practices, showed that there is an urgent need for improving the nutrient management of paddy-rice cultivation in Vietnam. Three rice-residue management practices were tested in the Luong Phong Commune (Bac Giang Province), (1) direct rice-residue incorporation into the soils after harvest, (2) application of rice-residue compost, and (3) burning of rice residues on the field. All three, together with non-adapted chemical fertilization, led to a surplus of $P$ in the range of $37-52 \mathrm{~kg} \mathrm{P} \mathrm{ha}^{-1}$ and of $\mathrm{K}$ in the range of $136-235 \mathrm{~kg} \mathrm{~K} \mathrm{ha}^{-1}$. These positive nutrient balances indicate a risk of excess nutrient accumulation in the soils. Such accumulation may potentially lead to eutrophication of adjacent water bodies. Surface- and groundwater around paddy-rice fields are especially at risk of eutrophication because the groundwater is often very close to the soil surface, and the temporary flooding of the rice fields provides a very direct nutrient pathway from the paddy fields to nearby surface-water bodies. Only for the rice fields in Che $\mathrm{Cu}$ Nha Commune (Yen Bai Province), from which rice residues were collected after harvest to be used as fodder for cattle, our study showed a risk of nutrient depletion. It was the only management that resulted in negative $\mathrm{N}, \mathrm{P}$, and $\mathrm{K}$ balances $\left(-21 \mathrm{~kg} \mathrm{~N} \mathrm{ha}^{-1},-2 \mathrm{~kg} \mathrm{P} \mathrm{ha}{ }^{-1},-61 \mathrm{~kg} \mathrm{~K} \mathrm{ha}^{-1}\right)$.

\section{Conclusions}

Based on these outcomes of our study, we draw two main conclusions for optimized rice-residue and fertilizer management:

I. We advise against the burning of rice residues. Given the limited availability of manure and labor force in the study regions, we recommend incorporating rice residues into the soils. This management technique is not very labor-intensive, and it has multiple benefits, as it returns nutrients to the soils, thus allowing for reducing the use of chemical fertilizers, and it adds organic matter to the soils, thus potentially increasing SOC contents.

II. Nutrient inputs need to be better adapted to the crop needs, as demonstrated by the unbalanced nutrient budgets of all the investigated systems in most of the studied cases resulting in nutrient accumulation and in one case resulting in nutrient depletion. Knowledge about (1) soil nutrient contents prior to planting, (2) expected harvest and corresponding nutrient uptake by plants, (3) 
nutrient concentrations in the rice residues, and nutrient balances resulting from the different rice-residue management practices, may help to optimize the fertilization practices to obtain high yields from paddy-rice fields without risking eutrophication of adjacent water bodies.

Author Contributions: D.T.H., M.K. and D.S. were responsible for conducting this research. H.J.H. contributed to data analysis.

Funding: This research was funded by the Vietnamese government, Grant No. 800/Q-D-BGDD.

Acknowledgments: We kindly thank staff at SFRI for all help and collaboration with the field and laboratory work. Many thanks to the farmer families in Luong Phong and Che Cu Nha commune, Nguyet, Phuong, Giap, Chua for their good collaboration.

Conflicts of Interest: The authors declare no conflict of interest.

\section{References}

1. GRiSP (Global Science Partnership). Rice Almanac 4th; International Rice Research Institute: Los Baños, Philippines, 2013.

2. FAO. Smallholders Data Portrait. Available online: http://www.fao.org/family-farming/data-sources / dataportrait/farm-size/en/ (accessed on 19 May 2017).

3. (GSO) General Statistics Office of Vietnam. Statistical Summary Book of Vietnam; Statistical Publishing House: Hanoi, Vietnam, 2017.

4. Gadde, B.; Bonnet, S.; Menke, C.; Garivait, S. Air pollutant emissions from rice straw open field burning in India, Thailand and the Philippines. Environ. Pollut. 2009, 157, 1554-1558. [CrossRef] [PubMed]

5. Tran, S.N.; Nguyen, T.H.N.; Nguyen, H.C.; Nguyen, V.C.N.; Le, H.V.; Kield, I. To quantify the seasonal rice straw and its use in different provinces in the Vietnamese Mekong Delta. J. Scie Can Tho Univ. 2014, 32, 87-93.

6. Truc, N.; Sumalde, Z.M.; Espaldon, M.; Pacardo, E.P.; Rapera, C.L.; Palis, F.G. Farmer's awareness and factors affecting adotion of rapid composting in Mekong delta, Vietnam and Central Luzon, Philippines. J. Environ. Sci. Manag. 2012, 15, 59-73.

7. Fairhurst, T.H.; Witt, C.; Buresh, R.J.; Dobermann, A. Rice: A Practical Guide to Nutrient Management, 2nd ed.; International Rice Research Institute: Los Baños, Philippines, 2007.

8. Niveta, J.; Arti, B.; Himanshu, P. Emission of air pollutants from crop residue burning in India. Aerosol Air Qual. Res. 2014, 14, 422-430. [CrossRef]

9. Gupta, P.K.; Sahai, S.; Singh, N.; Dixit, C.K.; Singh, D.P.; Sharma, C.; Tiwari, M.K.; Gupta, R.K.; Garg, S.C. Residue burning in rice-wheat cropping system: Causes and implications. Curr. Sci. 2004, 12, 1713-1717.

10. Ponnamperuma, F.N. Straw as a Source of Nutrients for Wet-Land Rice: Organic Matter and Rice; International Rice Research Institute: Manila, Philippines, 1984.

11. Bijay-Singh; Shan, Y.H.; Johnson-Beebout, S.E.; Yadvinder-Singh; Buresh, R.J. Crop Residue Management for Lowland Rice-Base Cropping Systems in Asia: Advances in Agronomy; Elsevier Inc.: Amsterdam, The Netherlands, 2008.

12. Hoang, N.T.; Tran, T.T.; Dao, T.H.; Nguyen, N.M.; Pham, T.N.; Nguyen, T.N.; Nguyen, H.T.; Vu, D.Q.; Ho, C.T. Effect of Agricultural Residues Incorporation into Soils on Increasing Crops Yield, Reducing Mineral Fertilizers Applied and Improving Soil Properties: The Rsults of Soils and Fertilizers Research; Agricultural Publishing: Hanoi, Vietnam, 2014.

13. Keck, M.; Hung, D.T. Burn or bury? A comparative cost-benefit analysis of crop residue management practices among smallholder rice farmers in northern Vietnam. Sustain. Sci. 2019, 14, 375-389. [CrossRef]

14. Tran, T.T.; Hung, T.D. Effect of crop by-product on yield and possibility of reducing potassium application rate for crops under rice-based cropping systems on marine sandy soils and grey-degraded soils. Vietnam Soil Sci. J. 2010, 33, 89-95.

15. Zhao, Y.; Wang, P.; Li, J.; Chen, Y.; Ying, X.; Liu, S. The effects of two organic manures on soil properties and crop yields on a temperate calcareous soil under a wheat-maize cropping system. Eur. J. Agron. 2009, 31, 36-42. [CrossRef]

16. (MARD) Ministry of Agriculture \& Rural Development. Annual Report 2017 of Fertilizers Sector; Ministry of Agriculture \& Rural Development: Hanoi, Vietnam, 2018. 
17. FAO. FAOSTAT Database. Available online: http://www.fao.org/faostat/en/\#data/EF (accessed on 24 April 2018).

18. Pham, Q.H.; Nguyen, V.B. Fertilizer and Mitigation of Greenhouse Gas Emission: National Workshop on Measures for Improving Fertilizer Use Efficiency in Vietnam (March 28, 2014); Agricultural Publishing: Hanoi, Vietnam, 2014.

19. Bui, H.H. Assessing the Present Use of Chemical Fertilizers and Promoting Methods to Improve the Use of Fertilizers for Crop Production in Vietnam; Soils and Fertilizers Research Institute: Hanoi, Vietnam, 2008.

20. Nguyen, V.B.; Tran, M.T.; Nguyen, V.C.; Le, T.; Bui, H.A.; Nguyen, T.T.; Chu, V.H.; Nguyen, H.; Bui, H.D.; Nguyen, D.; et al. Study on Determination of Limited Factors of Soils in Red River Delta, Mekong River Delta and Recommended Solutions; Soils and Fertilizers Research Institute: Hanoi, Vietnam, 2014.

21. Baumann, L. Insights into Vulnerability of Smallholder Farming Systems in the Upland Region of North Vietnam; Swiss Federal Institute of Technology: Zurich, Switzerland, 2014.

22. Cobo, J.G.; Dercon, G.; Cadisch, G. Nutrient balances in African land use systems across different spatial scales: A review of approaches, challenges and progress. Agric. Ecosyst. Environ. 2010, 136, 1-15. [CrossRef]

23. Stoorvogel, J.J.; Smaling, E.M.A. Assessment of Soil Nutrient Depletion in Sub-Saharan Africa; ISRIC: Wageningen, The Netherlands, 1990.

24. Abdalla, S.B.; Predotova, M.; Gebauer, J.; Buerkert, A. Horizontal nutrient flows and balances in irrigated urban gardens of Khartoum, Sudan. Nutr. Cycl. Agroecosyst. 2012, 92, 119-132. [CrossRef]

25. Huang, B.; Shi, X.; Yu, D.; Öborn, I.; Blombäck, K.; Pagella, T.F.; Wang, H.; Sun, W.; Sinclair, F.L. Environmental assessment of small-scale vegetable farming systems in peri-urban areas of the Yangtze River Delta Region, China. Agric. Ecosyst. Environ. 2006, 112, 391-402. [CrossRef]

26. Khai, N.M.; Ha, P.Q.; Öborn, I. Nutrient flows in small-scale peri-urban vegetable farming systems in Southeast Asia-A case study in Hanoi. Agric. Ecosyst. Environ. 2007, 122, 192-202. [CrossRef]

27. Phong, L.T.; Stoorvogel, J.J.; Van Mensvoort, M.E.F.; Udo, H.M.J. Modeling the soil nutrient balance of integrated agricultural aquaculture systems in the Mekong Delta, Vietnam. Nutr. Cycl. Agroecosyst. 2011, 90, 33-49. [CrossRef]

28. (GSO) General Statistics Office of Vietnam. Statistical Year Book of Vietnam; Statistical Publishing House: Hanoi, Vietnam, 2018.

29. Nguyen, V.B.; Bui, D.D.; Ho, Q.D.; Bui, H.H.; Dang, T.L.; Thai, P.; Nguyen, V.T. The Basic Information of Main Soil Units of Vietnam; The gioi: Hanoi, Vietnam, 2002.

30. Tran, Q.V.; Ho, Q.D.; Le, T.M.H.; Bui, T.Y. The situation of phosphorus in grey degraded soil in North Vietnam. Science and Technol. J. Agric. Rural Dev. 2013, 210-211, 24-30.

31. Nguyen, T.L.; Truong, X.C.; Nguyen, V.H.; Dinh, V.S. Survey and Evaluate Fertility Soils Map for Intensive Crop Restructuring and Sustainable Agricultural Land Resources Management in Viet Yen District, Yen Dung District, Luc Nam District, Yen District, Son Dong District and Bac Giang city, Bac Giang Province; Soils and Fertilizers Research Institute: Hanoi, Vietnam, 2015.

32. Truong, X.C.; Hoang, T.Q. Research on Terrace Field Land Use and Proposed Integrated Technical Solutions to Improve Efficiency Land Use in Yen Bai; Soils and Fertilizers Research Institute: Hanoi, Vietnam, 2013.

33. Hoang, A.L.; Nguyen, T.; Le, T.L. Estimated Gas Emission from Burning Rice Straw in Open Fields in Thai Binh Province. J. Sci. VNU 2013, 2, 26-33.

34. Doberman, A.; Fairhurst, T.H. Rice Nutrient Disorders \& Nutrient Management; International Rice Research Institute: Los Baños, Philippines, 2000.

35. Pham, Q.H.; Pham, T.H.; Nguyen, T.H.; Vu, D.T. Study on Nutrient Balance Based Intensive Cropping System; Soils and Fertilizers Research Institute: Hanoi, Vietnam, 2005.

36. Tran, Q.V.; Ho, Q.D.; Bui, H.D.; Tran, M.T. Assessment of the qualities, quantities, and properties of grey degraded soil in North Vietnam. Ministry of Agriculture and Rural development. Sci. Technol. J. Agric. Rural Dev. 2012, 207, 19-25.

37. (MARD) Ministry of Agriculture \& Rural Development. Apply Balance and Efficiency Fertilizer to Crops; Agricultural Publishing House: Hanoi, Vietnam, 1999.

38. Chien, N.V. Balance Fertilization-The Solution to Improving the Efficiency of Fertilizer Use in Vietnam. National Workshop on Measures for Improving Fertilizer Use Efficiency in Vietnam (March 28, 2014); Agricultural Publishing: Hanoi, Vietnam, 2014. 
39. Liu, X.; Herbert, S.J.; Hashemi, A.M.; Zhang, X.; Ding, G. Effects of agricultural management on soil organic matter and carbon transformation-A review. Plant Soil Environ. 2006, 52, 531-543. [CrossRef]

40. Turmel, M.-S.; Speratti, A.; Baudron, F.; Verhulst, N.; Govaerts, B. Crop residue management and soil health: A systems analysis. Agric. Syst. 2015, 134, 6-16. [CrossRef]

41. Lal, R. Managing Soils and Ecosystems for Mitigating Anthropogenic Carbon Emissions and Advancing Global Food Security. BioScience 2010, 60, 708-721. [CrossRef]

42. Hoang, N.; Tran, T.T.; Dao, T.H.; Vu, D.Q. Effect of crop by-product on yield of rice and maize under Spring rice-Summer rice-Winter maize cropping system on Red river alluvial soils, grey degraded soils and marine soils. Vietnam Soil Sci. J. 2010, 33, 95-106.

43. Ussiri, D.A.; Lal, R. Long-term tillage effects on soil carbon storage and carbon dioxide emissions in continuous corn cropping system from an alfisol in Ohio. Soil Tillage Res. 2009, 104, 39-47. [CrossRef]

44. Bui, D. An overview on fertilizer use in Vietnam. Vietnam Soil Sci. J. 1996, 6, 21-25.

45. Vu, T.; Tran, M.T.; Dang, T. A survey of manure management on pig farms in Northern Vietnam. Livest. Sci. 2007, 112, 288-297. [CrossRef]

46. (SFRI) Soils and Fertilizers Research Institute. Fertilizers Handbook; Agriculture Publishing House: Hanoi, Vietnam, 2005.

47. Pillot, D.; Le Coq, J.F.; Hoa, N.T.; Porphure, V. Stakeholders' Perception of Pig Effluent Management in Thai Binh Province: Pig Production Development, Animal Waste Management and Environment Protection: A case Study In Thai Binh Province, North Vietnam; CIRAD-PRISE Publication: France, 2006.

48. Phuong, N.D.; Tuan, V.D.; Toan, T.D. Farmers Practices in Organic and Inogarnic Fertilization on Crops, Trees and Vegetables: Pig Production Development, Animal Waste Management and Environment Protection: A case Study in Thai Binh Province, North Vietnam; CIRAD-PRISE Publication: France, 2006.

49. Öborn, I.; Edwards, A.; Witter, E.; Oenema, O.; Ivarsson, K.; Withers, P.; Nilsson, S.; Richert Stinzing, A. Element balances as a tool for sustainable nutrient management: A critical appraisal of their merits and limitations within an agronomic and environmental context. Eur. J. Agron. 2003, 20, 211-225. [CrossRef]

50. Muoi, N. Some Character of Gray Degraded Soil (Plinthic Acrisols) and Relationship between Those and Spring Rice Yield: Agriculture Science and Technology; Agricultural Publishing House: Hanoi, Vietnam, 1983.

51. Mi, L. The Results of Improving the Gray Degraded Soil (Plinthic Acrisols) in North Vietnam: Soils and Fertilizers Research Institute; Agricultural Publishing House: Hanoi, Vietnam, 1979.

52. Cancado, J.; Saldiva, P.; Pereira, L.; Lara, L.; Artaxo, P.; Martinelli, L.A.; Arbex, M.A.; Zanobetti, A.; Braga, A. The impact of sugar cane-burning emissions on the respiratory system of children and the elderly. Environ. Health Perspect. 2006, 114, 725-729. [CrossRef] [PubMed]

53. Awasthi, A.; Singh, N.; Mittal, S.; Gupta, P.K.; Agarwal, R. Effects of agriculture crop residue burning on children and young on PFTs in North West India. Sci. Total Environ. 2010, 408, 4440-4445. [CrossRef]

54. Hung, D.T.; Callum, C.B.; Sauer, D. Effect of crop residues and water management to $\mathrm{N}_{2} \mathrm{O}$ and $\mathrm{CH}_{4}$ emission from paddies rice in Vietnam. Unpublished, 2019.

(C) 2019 by the authors. Licensee MDPI, Basel, Switzerland. This article is an open access article distributed under the terms and conditions of the Creative Commons Attribution (CC BY) license (http://creativecommons.org/licenses/by/4.0/). 